\title{
Folklore Notes from St. Briavel's
}

\section{M. Eyre}

To cite this article: L. M. Eyre (1902) Folklore Notes from St. Briavel's, Folklore, 13:2, 170-177, DOI: $10.1080 / 0015587 X .1902 .9719676$

To link to this article: http://dx.doi.org/10.1080/0015587X.1902.9719676

$$
\text { 曲 Published online: } 06 \text { Feb } 2012 .
$$

Submit your article to this journal $₫$

Џll Article views: 1

Q View related articles ¿ 
The result, of course, was that the supplicants were either sold into slavery at Bende and the Misi Aro slave-markets, or, if old and unfit for slavery, or even too powerful chiefs, they were sacrificed. All sorts of stories are told of this mystery. Hundreds of people visited the place yearly, and never returned. Some who never absolutely saw the grotto, being blindfolded, stood in the water by the cave, and heard mysterious voices talking all round them, while the catfish nibbled at their feet and splashed about in the pool. If they were to die the water was supposed to pour out of the source the colour of blood. This was probably done by some rascally old priest inside the cavern. There is an entrance into the cavern at the back of the $\mathrm{Ju}-\mathrm{Ju}$, and there are to be seen the scaffold and sacrificial knife. The most loathsome thing about the place is the altar of skulls, the stack of captured arms, surmounted by a skull, and the alligators and catfish, which were fed after the sacrifices."

"Very, very little," snys Count de Cardi, writing to us, "has ever come to light as to what was actually carried on at the spot, and now that the whole place has been destroyed and the fetish priests scattered, I am afraid no more complete account will ever be compiled."... ED.

\section{Fot.klore Notes from St. Briavid's.}

(Rend at Mreating, 26th March, 1902.)

The village and common of St. I3riavel's stand on the edge of the Dean Forest, and though the common has long been enclosed, the old castle of the Constables is still the scene of Courts Leet, and the Crown officers go round yearly to spy out encroachments and the ravages of disforestable beasts. Sceing that the forest was at one time a sort of gathering place for gypsies, outlaws, and other turbulent folk, it is only natural that the present race should be small, dark, and untidy, whereas the people of the more fertile country are fair and rather pale. They are all expert poachers, but, outside the mining centres, share little interest in games or aports. Flower gardens, such as delight one in Kent, are 
of the rarest nccurrence, and generally belong to a "foreigner," that is, any person from another county. Such folklore as I have collected comes from my own village, or from places within six miles' distance. With the miners I am not in touch, and so could get nothing from them.

Tradition has it that st. Briavel, after whom the place was named, was once a Cornish king of such exceeding wickedness that his subjects rose and drove him out. After many wanderings he came to the Wye Valley, and, settling down, became a hermit, acquiring by his holiness great power over the wolves and other wild beasts of the forest. The site of his supposed hermitage is still known. A few stones in a wood go by the name of St. Margaret's Chapel, and to her the church is dedicated, but I have been unable to find out anything more about her. St. Briavel's Wells are three excellent springs on the hilltop, but have no connection with the Saint, who lived in the warm damp valley.

Offa's Dyke runs through the country side and is still plainly traceable, rising in some places to a height of fifteen feet, though almost ploughed away in others. The people call it the Devil's Dyke, but have no stories about it; nor have I been able to find any meanings for the queer names given to the different parts of the village-such as the Mork, the Meen, or Tumpkin's Ailes.

There are old Roman iron workings near by, with a Devil's Chapel and a Devil's Kitchen; also a stone put up to commemorate the murder of one of the Constables of the Forest (this bleeds if you stick a pin into it); and many other interesting places. 'These do not, however, belong properly to St. Briavel's.

of the local omens, charms, folk-medicine, customs and sayings, witchcraft and fairy legends, mast will probably be known already to the Socjety, but one or two things are, I think, new.

First comes the usual list of crows or magpies: one, for ill; two, for good; three, a disappointment; four, a letter; five, something better; six, a wedding; seven, a burying. But there is a small local variant which says that although one crow in the morning brings ill-luck and two good, yet one after dinner brings good fortune.

If a bee comes into the house, a stranger will soon arrive. In the spring, if you see the first young lamb back first, it is unlucky, you will go backwards all the year.

The small egg first laid by a pullet should never be brought 
into the house, but should be thrown over the roof, that the illluck may pass over the household.

When there is a letter in the candle, you thump on the table until the spark falls off --so many thumus, so many days before the letter will arrive.

It is very unlucky to be offered money for any object ; if a fair price be offered you should sell, as ill will come if you refuse.

It is "dreadful bad luck" to put a lanthorn on the table, but if you should have done so foolish a thing, throw salt on the fire, "for if you do waste the salt, you stop the luck." 'This applies also to other ill-omened actions.

There is a curious and unexpectedly tidy custom of drawing a line of white round the walls of the living-room and round the top doorstep, or the stone sill should there be no steps. The line must be unbroken, for then the evil spirits cannot enter the house.

Should you be troubled by unexplained illness and death amongst your pigs, you should bury the poor victints toes upwards, and the trouble will cease.

There are various deathromens; for instance, should an owl sit on the roof and whoop, or if a bird enters the house, or even when one "fetches up" against the windows, it bodes ill. "An old man did die along of Louie Jones, and 1 could not drive that bird away along until him was dead," as an old woman told me in proof of this last omen. A winding sheet in the candle of course bodes ill, and should you hear a sound like the stroke of a stick on a chair, you may be certain that there will be a death in the family shortly. Finally, should it thunder and lighten at a funeral, it does not speak well for the future happiness of the deceased.

Weather sayings are few and commonplace-cats playing about, cows lying down, valley-fog climbing the hill, all mean rain. When the mist lies flat, there will be hot weather. Pigs can smell the wind, and geese flying over forecast rough weather at sea.

Afedicine of course comes naturally to the seventh son of a seventh son, but if your child has whooping-cough, and you do not wish to consult a doctor, wait until you meet a man leading a piebald horse, "and whatever him do say will cure the cough." Or pass the sickly child nine times over and under a bramble that is rooted at both ends. 
To secure freedom from toothache you should always carry in your pocket one of those mossy balls that are often found growing on wild rose trees. We used to call them "King o' the Roses." I do not know the real name. ${ }^{1}$ But if you have toothache, it can be cured by sitting under an ash-tree and cutting your toe-nails.

The forefoot of an unt (or mole) should be carried as a preservative against rheumatism, and a drink of Barrow Well water, on going to bed, is good for a cold.

A Good Friday cake is good for internal troubles. You grate a little into water, and take it so. There is nothing special about the making of this cake, except the date, nor is it cake in the ordinary sense, being merely a lump of dough from the usual baking. The remnants left over are always made into small, flat, cheese-shaped loaves called "batch-cakes," and I fancy the Good Friday cakes are of the same type.

The following charms are used, first, to prevent a wound from festering, the second, to stop the flow of blood. They should be said "over" the injured part :-

Charm for a Thorn. - Our Saviour was born in Bethlehem, pierced with spears, nails, and thorns. Whose wounds never gathered, smarted, nor festered, no more than this thorn. In the name of the Father [etc.]. Amen.

Charm for Blood.-Our Saviour was born in Bethlehem, baptised by John the Baptist in the river of Jordan. Although the waters was wild the waters was good. Christ commanded the waters to stand and the waters stood-so stand this blood. Ribaduck" go no more. In the name of God, I stop this bloud. Amen.

The Local Customs are some of them very commonplace, such as sitting up with a corpse until it be buried, and opening all the windows of the house where it lies, that the spirit may escape. But instead of telling the bees of a death, they lift the hives as the corpse is raised to go to the churchyard. If this be neglected, they will die. On Cox Hill there is a stone, where burying parties always rest and set down the corpse. $U_{p}$ to this point volunteers may carry the coffin, but thence to the churchyard the proper bearers take up their duty.

St. Thomas' Day is locally known as "Gooding Day," for then

'TThe gall of the wild rose, formed by the insect Cyvis Rosif, is what is meant.-IED.]

*I cannot explain this word. If was not given when the charm was repented to me, but appeared in the written copy sent me afterwards. 
poor people go from house to house begging: "Please to give against a good day." Wheat for bread was often given.

On Christmas Eve at miduight, the cattle kneel and the rosemary bursts into flower - "people used to sit up to see it, down in the Meen." It is also said that where the rosemary grows well "the mistress is master."

First foot, either on ('hristmas or New Year's I)ay, should be a man, for luck's sake.

Those watching in a churchyard between twelve and one at night on New Year's Eve, will see the people who are to die within the year.

On New Year's 1)ay you should get the newest pin you can and drop it in the water, "because it is the blood of Christ." I can get no explanation of this saying.

'There is a very pretty custom that is now dying out, which I can, however, illustrate by an exhibit, ${ }^{1}$ of presenting on New Year's Day, what they call "The gift." It is an apple set on three wooden legs, and having a sprig of box, hung with hazel nuts, stuck into it after the manner of a Christmas tree.

In old days, it used to be customary to light twelve small fires in the cornficlds on Christmas Eve that there might be a good crop.

On old New Year's Day you should burn the Christmas holly.

On "Soft "luesday" there should be pancakes.

Mothering Sunday is a well-established custom with us, and the following is Fathering Sunday. Sweet cakes are made for both occasions.

Palm Sunday is called "Flowering Sunday," and all graves are dressed with flowers. It is a very pretty sight, and there is some rivalry between the different villages as to which shall turn out the best decorated churchyard. Parties go round visiting from church to church, looking and comparing." I was told the origin of the custom is this: "It says in the Bible, that the day Jesus Christ was buried, people strewed palm-leaves on the road

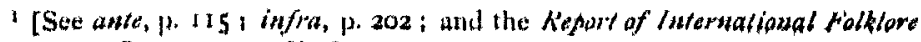
Congress, 1891, p. $452,-101$.

"[Noted in Wales by Mr. A. J. C. J Jare, L.iffe of Baroness Busesen, ii., 392 ; and a spuradic (?) instance at Albrigthon, near Wolverhampton, shropikire folklore, 330-- So. I am quite familiar with the custom, which is practlsed everywhere in Wales.-IA. S. If.] 
they were taking Him, and made wreaths and crosses of them, and they called it Palm sunday."

"Cursed is the woman that wash and dry of a Good Friday."

People used to run for dresses and little things at Easter and Whitsuntide, but now we have a regular sort of fair, called the "Revels," at which there are races.

The Society knows, from Mr. Hartland's Glowcestershire Folklore, that we rejoice in a local variant of the Godiva story, and that from the reign of John the Commoners have had certain rights in the free wood of Hudnalls. The Society has also read that it was customary to throw bread and cheese to be scrambled for on Whit Sunday. The connection between the two is this: "The Lady did give it, and the bread and cheese was throwd a' Whitsun Sunday to keep this charter up. People did go round the houses to collect a penny each to buy the bread and cheese."

Ghosts there are in plenty. The Castle naturally has its White Lady and its Man in Armour. At Lindors there is a phantom fiddler. "Things with eyes like saucers" and men in "they old box-hats" are met in the lanes, and funerals are seen at three a.m. of a summer's morning.

Witchcraft is still a power, and I will begin by telling you how to become a witch ; it is fairly easy, as all you need to do is to walk twelve times round a church backwards, at midnight. Then when you are a witch you can "run" as a hare or a rabbit. Witches used to tie the manes and tails of the horses at Lindors. If a witch be refused anything at a house, she will have revenge on the animals or children, and will cause them to bleed to death or become paralysed. To prevent a witch from coming into the house, nail a cross of quicken (hawthorn) behind the door, or a yew stick, and plant quicken-trees near your yards and pig-cotes. To find out a witch, get a piece of leather, and fill it with pins; stick them in different ways, and burn it. At the time of burning, the person who is the witch will come to the door.

There is now a very malevolent witch in the village of Whitebrook, who brings to sorrow those who do not cheerfully give her whatever she may ask for. One poor woman refused some request, whereupon the dame swore that the ungenerous creature should lose all her cows. Now, she had no cattle. But so great was the power of the curse that she went mad, and wanders about the 
woods seeking and calling the phantom cows that she thinks herself to have lost.

Again, in St. Briavel's itself, some years ago a cottager offencled his neighbours, and one fine Sunday afternoon when he and his family tried to re-enter their cottage after a walk, they found the door so fast shut that it had finally to be broken open with a pickaxe. This was undoubted witchcraft.

The vicar of the neighbouring parish of Newlands one day called his man in from mowing the hay to see to something that was needed in a hurry. To his surprise, instead of coming at once, the man stopped to carefully sharpen the scythe, and to set it aside, edge upwards. On his return he said to the parson, "You don't know why I sharpened my scythe before going? I'll tell 'ee. If I'd ha' left that there scythe unsharpened, look see, and an old witch had come along and seen it, she'd ha' rid that scythe round and round the field, and it wouldn't never have had no edge to cut with no more!" "And I went from there," said the clergyman, in telling the story, "to the churchwarden's house, and found him, with all his family, standing round making charms to make the butter come."

Old people have told me various tales of witches in their young days; how they gave charms that were better than any doctor's stuff, and notably one story of how a young girl put up for the night with a widow and her daughter. The cottage was small and the guest shared her hostess's bed. It was a fearful night and the noise of the storm kept the young girl awake. In her restless turning, her hand happened to touch the old woman, who was stone-cold, and in her horror she cried out: "Oh! your mother be dead." "1)ad," laughed the daughter, "her ben't dead, her be out and about now!"

Passing from Witches to Fairies, the belief is weaker. They have not been seen for many years, though they used to dance in the Mork, and were "like little soldiers." But we can boast of one fairy-tale which is, I think, quite local.

There was once a farmer of the name of John Jones, who lived in the Mork. He had had a bad year and was hard put to it to pay his rent, so he decided to sell some cider, and started out with the intention of offering it round. As he left the house he met a man who said, "John, do you want to sell some cider?" "Yes," said John, and after some discussion they settled on a 
price. "Very well," said the man, "now this is what you must do. Carry a hogshead of cider down to the Fairy Ring in the Big Meadow, and pour it out there on to the grass within the ring," With that he paid and went away. As soon as he was gone, the farmer began to think what a shame it was to waste so much good cider, and the more he thought the less he felt inclined to do it. He bad the money safe, and the Fairy Folk would never know the difference, so when evening came he rolled down a hogshead of water and poured that out within the ring. No sooner, however, did he step outside the ring than he saw the same man who had bargained with him in the morning, very angry and threatening. He cursed John Jones and all his family, saying that as he had tried to cheat, the curse should not be lifted until he and his had lost as much blood as water bad been poured down the ring. "And they do say," my informant told me cheerfully, "as how a power o' that family did bleed to death !"

There is only one nursery rhyme that I have found, and to my mind it explains why some of the local babies look so pale and sad.

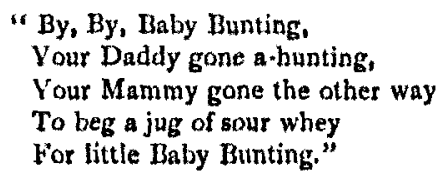

I will conclude with a rhyme obviously composed by our envious neighbours.

\footnotetext{
" St. Briavel's stands upon a hill.

It has a church without a steeple, looks down on the River Wye, With most deceitful people."
}

L. M. EYRE.

\section{Hakvest Customs.}

(Ante, vol, xii., p. 215, and supra, p. 113.)

Continuing my notes on Derwickshire Harvest Customs, I send the following extracts from a letter of Mr. W. Lockie of Kelso, recently forwarded to me by Mr. A. Falconer of Dunsi

vor. $x$ III 